$\delta$ ELT $\Delta$

Jurnal Ilmiah Pendidikan Matematika

p.ISSN: 2303 -3983 e.ISSN:2548-3994

Vol. 7 No. 2 Juli 2019 Hal $65-72$

\title{
Analisis Kesulitan Siswa Dalam Menyelesaikan Soal-Soal HOTS Materi Segiempat dan Segitiga Ditinjau dari Gender
}

\author{
Lulun Indraswari, Anggun Wiji Lestari, Ratri Candra Hastari 3 \\ ${ }^{1,2,3}$ Pendidikan Matematika, STKIP PGRI Tulungagung \\ Jalan Mayor sujadi Timur No.7 Tulungagung \\ Lulunindraswari@gmail.com
}

\begin{abstract}
Abstrak
Penelitian ini bertujuan untuk mengetahui kesulitan dan faktor-faktor penyebab dalam menyelesaikan soal-soal HOTS Siswa SMP ditinjau dari gender. Penelitian ini adalah jenis penelitian deskriptif dengan pendekatan yang digunakan adalah pendekatan kualitatif. Penelitian ini di laksanakan di SMP N 1 Pogalan Trenggalek. Subjek penelitian yaitu 31 siswa kelas VII F. Instrumen yang digunakan berupa RPP, soal tes, dan lembar observasi. Hasil analisis menunjukkan bahwa kesulitan yang dialami siswa dalam menyelesaikan soalsoal HOTS menunjukkan bahwa siswa laki-laki mengalami kesulitan pada tahap analisis dan evaluasi sedangkan siswa perempuan mengalami kesulitan pada tahap evaluasi dan mencipta. Adapun faktor-faktor penyebab kesulitan yang dialami siswa adalah siswa tidak terbiasa untuk menyelesaikan soal yang berhubungan dengan materi tersebut, siswa kurang tertarik dalam mempelajari materi segiempat, serta siswa cenderung bergantung pada bantuan guru.
\end{abstract}

Kata kunci: Gender, HOTS, Segiempat dan Segitiga.

\section{Abstrack}

This study aims to determine the difficulties and causal factors in solving questions about the HOTS of junior high school students in terms of gender. This research is a type of descriptive research with the approach used is a qualitative approach. This research was carried out in state junior high school 1 Pogalan Trenggalek. The research subjects were 7 students in grade VII F. The instrument used is a learning implementation plan, test questions, and observation sheets. The results of the analysis indicate that the difficulties experienced by students in completing questions about HOTS indicate that male students have difficulty in the analysis and evaluation stage while female students have difficulty in the stage of evaluation and creating. As for the factors that cause difficulties experienced by students are students are not accustomed to solving questions related to the material, students are less interested in the material, an students tend to depend on the help of the teacher.

Kata kunci: Gender, HOTS, Quadrilateral and Triangle.

\section{PENDAHULUAN}

Tujuan utama dari high order thinking skills adalah bagaimana meningkatkan kemampuan berpikir peserta didik pada level yang lebih tinggi, terutama yang berkaitan dengan kemampuan untuk berpikir secara kritis dalam menerima berbagai jenis informasi, berpikir kreatif dalam memecahkan suatu masalah menggunakan pengetahuan yang dimiliki serta membuat keputusan dalam situasi-situasi yang kompleks (Saputra, 2016:91-92) dalam artikel (Husna Nur Dinni, 2018). Konsep dari high order thinking skills didasari oleh beberapa pendapat, seperti bisa dilihat pada tabel berikut: 


\begin{tabular}{llll} 
& Tabel 1.1. Dasar Konsep & High Order Thinking Skills \\
\hline $\begin{array}{l}\text { Problem Solving } \\
\text { Krulik \& Rudnick } \\
\mathbf{1 9 9 8 )}\end{array}$ & $\begin{array}{l}\text { Taksonomi Kognitif } \\
\text { Bloom Original }\end{array}$ & $\begin{array}{l}\text { Taksonomi Bloom } \\
\text { Revisi Ander \& } \\
\text { Krathwohl (2001) }\end{array}$ & $\begin{array}{l}\text { High Order Thinking } \\
\text { Skills }\end{array}$ \\
\hline Recall & Knowledge & Remember & \\
Basic (Dasar) & Comprehense & Understand & \\
& Application & Apply & \\
\hline Critical & Analysis & Analize & Critical Thinking \\
Creative & Synthesis & Evaluate & Creative Thinking \\
& Evaluation & Create & Problem Solving \\
& & & Decision Making \\
\hline
\end{tabular}

Ketiga konsep di atas yang menjadi dasar high order thinking skills merujuk pada aktivitas menganalisis, mengevaluasi, mencipta pengetahuan yang disesuaikan dengan konseptual, prosedural dan metakognitif. Menurut Krathwohl (2002) dalam A revision of Bloom's Taxonomy, menyatakan bahwa indikator untuk mengukur kemampuan berpikir tingkat tinggi meliputi menganalisis (C4) yaitu kemampuan memisahkan konsep ke dalam beberapa komponen dan menghubungkan satu sama lain untuk memperoleh pemahaman atas konsep secara utuh, mengevaluasi (C5) yaitu kemampuan menetapkan derajat sesuatu berdasarkan norma, kriteria atau patokan tertentu, dan mencipta (C6) yaitu kemampuan memadukan unsur-unsur menjadi sesuatu bentuk baru yang utuh dan luas, atau membuat sesuatu yang orisinil.

Keterampilan berfikir tingkat tinggi dalam suatu pendidikan dapat diukur, yaitu dengan adanya ujian. Ujian Akhir Semester (UAS) untuk tingkat SMP telah dilaksanakan. Ujian diikuti oleh para siswa-siswi yang sedang berada pada tingkatan kelas 9. Berkaitan dengan gender, H. T. Wilson mengartikan gender sebagai suatu dasar untuk menentukan perbedaan sumbangan laki-laki dan perempuan pada kebudayaan dan kehidupan kolektif yang sebagai akibatnya mereka menjadi laki-laki dan perempuan. Elaine Showalter menyebutkan bahwa gender lebih dari sekedar pembedaan laki-laki dan perempuan dilihat dari konstruksi sosial budaya (Nasaruddin Umar, 2010: 30). Indikator kunci pembelajaran peka gender yaitu:

1. Perencanaan Pembelajaran 
2. Materi bahan ajar

3. Metode Pembelajaran

4. Lingkungan Pembelajaran

5. Pendidik

6. Penilaian Hasil Belajar

Dalam penelitian ini kesulitan yang digunakan adalah kesulitan menurut

Cooney (dalam Abdurrahman, 2003: 278) dalam artikel (Lailli Ma'atus Sholekah, dkk, 2017) kesulitan dikategorikan dalam 3 jenis, yaitu: a) kesulitan dalam mempelajari konsep (kesulitan dalam mempelajari konsep dalam satu materi), b) kesulitan dalam menerapkan prinsip (kesulitan dalam menerapkan konsep yang artinya kesulitan dalam mengkaitkan konsep antar materi), c) kesulitan dalam menyelesaikan masalah verbal (kesulitan dalam menyelesaikan soal- soal yang berhubungan dengan masalah verbal atau soal cerita).

\section{METODE PENELITIAN}

Jenis penelitian ini adalah penelitian kualitatif. Penelitian kualitatif merupakan salah satu metode penelitian yang bersifat deskriptif dan cenderung mencari sebuah makna dari data yang didapatkan dari hasil sebuah penelitian. Peneliti dalam penelitian menggunakan jenis pendekatan studi kasus. Jenis pendekatan tersebut merupakan jenis pendekatan yang digunakan untuk menyelidiki dan memahami sebuah kejadian atau masalah yang telah terjadi dengan mengumpulkan berbagai macam informasi yang kemudian diolah untuk mendapatkan sebuah solusi agar masalah yang diungkap dapat terselesaikan.

Pengambilan subjek penelitian berdasarkan teknik Purposive Sampling. Subjek penelitian yang terpilih yaitu sebanyak 7 siswa yang terdiri dari 3 laki-laki dan 4 perempuan. Teknik pengambilan subjek yaitu memilih siswa yang mudah diajak komunikasi, siswa yang memiliki kemampuan rendah dalam materi segiempat, dan menurut pertimbangan dari guru matematika. Subjek yang terpilih adalah BP, SB, SM, LB, LO, RP, BW. 
a. Teknik pengumpulan data pada penelitian ini menggunakan tes tertulis, wawancara, dan observasi. Setiap instrumen divalidasi oleh 2 orang validator yaitu guru matematika dan dosen matematika. Dalam penelitian ini soal tes berkarakter HOTS dengan menggunakan materi segiempat dan segitiga untuk mengetahui kesulitan siswa dalam menyelesaikan soal-soal HOTS ditinjau dari gender. Setiap tes menunjukkan indikator HOTS yang meliputi: 1) Menguraikan ukuran panjang dan lebar bangun segiempat, 2) Menentukan luas bangun datar segiempat, 3) Mengembangkan jumlah bangun datar yang dapat terbentuk diatasnya. Jawaban siswa yang sudah dianalisis kemudian didaftar kesulitan apa sajakah yang dialami siswa. Hasil tes akan menunjukkan pada indikator apa siswa akan mengalami kesulitan baik satu indikator maupun ketiganya yaitu analisis, evaluasi, dan mencipta. Dalam wawancara perlu diketahui bahwa peranan pewawancara yaitu terampil dalam menghayati setiap pertanyaan, peranan responden yaitu terampil dalam menjabarkan jawaban, serta teknik didalam wawancara yaitu berkaitan dengan cara bertanya, cara menjawab, dan penampilan. Pertanyaan diajukan ketika siswa mengerjakan tes. Dengan demikian hasil wawancara ditulis pada daftar tabel yang telah dibuat sebelumnya.

Untuk menjamin keabsahan data dalam penelitian ini menggunakan uji keabsahan data penelitian kualitatif meliputi uji: Credibility (validitas internal), penelitian ini menggunakan triangulasi teknik atau metode, yaitu dengan cara membandingkan hasil tes, hasil wawancara, dan hasil observasi, Transferability (validitas eksternal), peneliti dalam membuat laporan memberikan uraian yang rinci, jelas, sistematis, dan dapat dipercaya, Dependability (reliabilitas), peneliti melakukan proses penelitian ke lapangan untuk pengambilan data, Confirmability (obyektivitas), hasil penelitian peneliti disepakati banyak orang. Menguji confirmability berarti menguji hasil penelitian, dikaitkan dengan proses yang dilakukan (Lailli M.S, 2017). 


\section{HASIL DAN PEMBAHASAN}

Hasil validasi RPP sebagai bahan pendukung proses pembelajaran yang terdiri dari 4 aspek yang dinilai. Secara keseluruhan pada aspek perumusan tujuan pembelajaran mendapatkan nilai rata-rata sebesar 4,1 yang tergolong dalam kategori Baik. Pada aspek isi yang disajikan mendapatkan nilai rata-rata sebesar 4 yang tergolong dalam kategori Baik. Pada aspek bahasa mendapatkan nilai rata-rata sebesar 4 yang tergolong dalam kategori Baik. Pada aspek waktu mendapatkan nilai rata-rata sebesar 4 yang tergolong dalam kategori Baik. Sedangkan hasil validasi soal tes menunjukkan bahwa terdapat bahasa yang kurang tepat dalam soal dan terdapatnya kalimat perintah pengerjaan soal yang belum jelas sehingga perlu pembenahan. Berikut soal tes yang sudah tervalidasi.

Tabel 3.1 Instrumen Penilaian Soal Tes

Kalimat soal
Jawablah pertanyaan dibawah ini beserta langkah-langkahnya!
1. Terdapat 1 lembar kertas persegi panjang dengan ukuran $30 \mathrm{~cm}^{2} \mathrm{x} 50 \mathrm{~cm}^{2}$.
Berapa banyak amplop yang bisa dibuat dari kertas tersebut jika satu amplop
yang berbentuk persegi memiliki ukuran sisi $5 \mathrm{~cm}^{2}$ ?
2. Azzahra memiliki sepotong kain yang berbentuk persegi panjang. Ia
berencana menghias sekeliling kain tersebut dengan renda. Jika ternyata
renda yang diperlukan Azzahra paling sedikit $450 \mathrm{~cm}$, berapakah salah satu
ukuran kain yang dimiliki Azzahra?

Sumber: Peneliti, 2019

Dari data hasil analisis (lembar jawaban, wawancara, dan observasi) tujuh siswa yang ikut serta dalam penelitian secara utuh peneliti berpendapat bahwa terdapat berbagai macam kesulitan dan faktor yang menyebabkan siswa kesulitan dalam menyelesaikan soal-soal High Order Thinking Skills. Peneliti akan memaparkan kesulitan serta faktor-faktor yang dialami tiap siswa ditinjau dari gender kedalam tabel berikut.

Tabel 3.2 Kesulitan dan Faktor-faktornya

\begin{tabular}{lcll}
\hline $\begin{array}{c}\text { Nama } \\
\text { (inisial) }\end{array}$ & $\begin{array}{c}\text { Jenis } \\
\text { Kelamin }\end{array}$ & \multicolumn{1}{c}{ Kesulitan } & \multicolumn{1}{c}{ Faktor-faktornya } \\
\hline BP & Laki-laki & $\begin{array}{l}\text { Tidak mampu memperkirakan } \\
\text { ukuran kain (tahap analisis) }\end{array}$ & $\begin{array}{l}\text { Tidak mengikuti pembelajaran } \\
\text { dengan baik dan takut bertanya } \\
\text { pada guru } \\
\text { Takut dengan mata pelajaran } \\
\end{array}$ \\
& & & matematika
\end{tabular}




\begin{tabular}{|c|c|c|c|}
\hline SB & Perempuan & $\begin{array}{llr}\text { Menentukan jumlah luas } \\
\text { amplop dan kertas } \\
\text { mengevaluasi) }\end{array}$ & $\begin{array}{l}\text { Cenderung tidak mengerjakan } \\
\text { sendiri, bergantung pada guru }\end{array}$ \\
\hline & & $\begin{array}{l}\text { Menentukan banyak amplop } \\
\text { yang terbentuk dan ukuran } \\
\text { kain (tahap mencipta) }\end{array}$ & $\begin{array}{l}\text { K13 dimana siswa dituntut } \\
\text { untuk mandiri }\end{array}$ \\
\hline SM & Perempuan & $\begin{array}{l}\text { Mensubstitusikan persoalan } \\
\text { (tahap mengevaluasi) }\end{array}$ & $\begin{array}{l}\text { Kurang pandai dalam } \\
\text { perhitungan matematis dan }\end{array}$ \\
\hline & & $\begin{array}{l}\text { Menentukan ukuran kain } \\
\text { (tahap mencipta) }\end{array}$ & $\begin{array}{l}\text { juga siswa kurang latihan } \\
\text { menyelesaikan soal. }\end{array}$ \\
\hline LB & Perempuan & $\begin{array}{l}\text { Menentukan ukuran kain } \\
\text { dengan strategi yang urut dan } \\
\text { benar (tahap mengevaluasi) }\end{array}$ & $\begin{array}{l}\text { Kurang teliti dan fokus dalam } \\
\text { menjalankan strategi }\end{array}$ \\
\hline $\mathrm{LO}$ & Perempuan & $\begin{array}{l}\text { Menentukan ukuran kain } \\
\text { dengan strategi yang urut dan } \\
\text { benar (tahap mengevaluasi) }\end{array}$ & $\begin{array}{l}\text { Siswa kurang teliti dan sering } \\
\text { tertinggal disaat penjelasan } \\
\text { materi }\end{array}$ \\
\hline RP & Laki-laki & $\begin{array}{l}\text { Menentukan ukuran kain } \\
\text { dengan strategi yang urut dan } \\
\text { benar (tahap mengevaluasi) }\end{array}$ & $\begin{array}{l}\text { Siswa kurang teliti dan kurang } \\
\text { latihan }\end{array}$ \\
\hline BW & Laki-laki & $\begin{array}{l}\text { Menentukan ukuran kain } \\
\text { dengan strategi yang urut dan } \\
\text { benar (tahap mengevaluasi) }\end{array}$ & $\begin{array}{l}\text { Kurang mampu berhitung } \\
\text { secara matematis dan kurang } \\
\text { latihan }\end{array}$ \\
\hline
\end{tabular}

Sumber: Peneliti, 2019

Berdasarkan data yang diperoleh, dapat diketahui bahwa dari 2 soal tes siswa hanya bisa mengerjakan satu soal dengan benar. Dengan kata lain, setiap subjek siswa mengalami kesulitan yang berbeda pada indikator HOTS.

\section{KESIMPULAN}

Berdasarkan penelitian, pengolahan dan analisis data yang terkumpul berkenaan dengan kesulitan siswa dan faktor-faktor penyebab dalam menyelesaikan soal-soal HOTS ditinjau dari gender siswa SMP Negeri 1 Pogalan, maka dapat disimpulkan bahwa:

1. Kesulitan dan faktor-faktor penyebab yang dialami subjek siswa laki-laki

a. Tahap analisis

Siswa tidak mampu memperkirakan ukuran kain. Pada tingkatan ini siswa cenderung mengalami kesulitan dalam mempelajari konsep. Adapun faktor penyebabnya yaitu siswa tidak mengikuti pembelajaran dengan baik.

b. Tahap evaluasi 
Siswa tidak mampu menentukan ukuran kain dengan strategi yang urut dan benar. Pada tingkatan ini siswa cenderung mengalami kesulitan pada indikator menerapkan prinsip. Adapun faktor penyebabnya yaitu siswa kurang teliti, kurang latihan.

2. Kesulitan dan faktor-faktor penyebab yang dialami subjek siswa perempuan

a. Tahap evaluasi

Siswa tidak mampu menentukan jumlah luas amplop dan kertas, mensubstitusikan persoalan, dan menentukan ukuran kain dengan urutan strategi yang urut dan benar. Pada tingkatan ini siswa cenderung mengalami kesulitan pada indikator menerapkan prinsip. Adapun faktor penyebabnya yaitu siswa kurang teliti, kurang fokus, dan sering tertinggal saat penjelasan materi.

b. Tahap mencipta siswa tidak mampu menentukan banyak amplop yang terbentuk dan ukuran kain. Pada tingkatan ini siswa cenderung mengalami kesulitan dalam indikator menyelesaikan masalah verbal. Adapun faktor penyebabnya yaitu siswa kurang latihan.

\section{DAFTAR PUSTAKA}

Asviangga, A. B., Sunardi, \& Trapsilasiwi, D. (2018). ANALISIS KEMAMPUAN 4C's SISWA DALAM MENYELESAIKAN SOAL MATEMATIKA BERPIKIR TINGKAT TINGGI. Kadikma, 8(1), 1723.

Gais, Z., \& Afriansyah, E. A. (2017). ANALISIS KEMAMPUAN SISWA DALAM MENYELESAIKAN SOAL HIGH ORDER THINKING DITINJAU DARI KEMAMPUAN AWAL MATEMATIS SISWA. Jurnal Mosharafa, 6(2), 251-262.

Nurhasanah. (2018). KEMAMPUAN PEMECAHAN MASALAH DAN PENALARAN MATEMATIS SOAL HIGH ORDER THINKING SKILL SISWA SMP PADA PENERAPAN METODE STUDENT TEAMS ACHIEVEMENT DIVISIONS (STAD) DENGAN PENDEKATAN PROBLEM BASED LEARNING (PBL). Retrieved from http://e-journal.uajy.ac.id/14649/1/JURNAL.pdf

Rasiman, \& Asmarani, F. (2016). ANALISIS KESULITAN SISWA SMP DALAM MENYELESAIKAN MASALAH MATEMATIKA DITINJAU DARI GAYA KOGNITIF. Jurnal Ilmiah Pendidikan Matematika, 1(2), 1-13. 
Rizal, M. (2018). PENGEMBANGAN LKPD MATEMATIKA BERBASIS PROBLEM BASED LEARNING UNTUK MENINGKATKAN KEMAMPUAN HIGHER ORDER THINKING SKILLS PESERTA DIDIK KELAS IV SD. UNIVERSITAS LAMPUNG. Retrieved from http://ejournal.uajy.ac.id/14649/1/JURNAL.pdf

Hadi, S., Munadi, S., \& Retnawati, H. (2013). KESULITAN SISWA SMA DALAM MENGERJAKAN SOAL YANG MENGUKUR HOTS. Retrieved from http://ejournal.uajy.ac.id/14649/1/JURNAL.pdf

Musfiqi, S., \& Jailani, J. (2014). PENGEMBANGAN BAHAN AJAR MATEMATIKA YANG BERORIENTASI PADA KARAKTER DAN HIGHER ORDER THINKING SKILL (HOTS). PYTHAGORAS: Jurnal Pendidikan Matematika, 9(1), 45-59.

Ekawati, Aminah., \& Shinta Wulandari. (2011). PERBEDAAN JENIS KELAMIN TERHADAP KEMAMPUAN SISWA DALAM MATA PELAJARAN MATEMATIKA (STUDI KASUS SEKOLAH DASAR). Jurnal Socioscientia Kopertis, 3: 19-24.

Sholekah, L. M., Anggreini, D., \& Waluyo, A. (2017). ANALISIS KESULITAN SISWA DALAM MENYELESAIKAN SOAL MATEMATIKA DITINJAU DARI KONEKSI MATEMATIS MATERI LIMIT FUNGSI. Wacana Akademika Volume, 1(2), 151-164.

Dinni, Husna Nur. (2018). HOTS (HIGHER ORDER THINKING SKILLS) DAN KAITANNYA DENGAN KEMAMPUAN LITERASI MATEMATIKA. Retrieved from https://journal.unnes.ac.id/sju/index.php/PRISMA.pdf 